\title{
Lumen
}

Selected Proceedings from the Canadian Society for Eighteenth-Century Studies

\section{'You're not a genius just because you're mad': Imitation and Originality in the Swedish Enlightenment}

\section{Michael B. Thompson}

Volume 13, 1994

URI : https://id.erudit.org/iderudit/1012532ar

DOI : https://doi.org/10.7202/1012532ar

Aller au sommaire du numéro

Éditeur(s)

Canadian Society for Eighteenth-Century Studies / Société canadienne d'étude du dix-huitième siècle

ISSN

1209-3696 (imprimé)

1927-8284 (numérique)

Découvrir la revue

Citer cet article

Thompson, M. B. (1994). 'You're not a genius just because you're mad':

Imitation and Originality in the Swedish Enlightenment. Lumen, 13, 169-177.

https://doi.org/10.7202/1012532ar 


\section{5. 'You're not a genius just because you're mad': Imitation and Originality in the Swedish Enlightenment}

[Professor Thompson, who delivered this paper to the 1992 conference in absentia on a video-tape, died from cancer shortly thereafter. The translations are assumed to be his own: Mike was a glutton for languages as well as marathons, which took him to Stockholm, where he deepened his acquaintance with Kellgren, Bellman and other eighteenth-century Swedish writers. According to The Blackwell Companion to the Enlightenment, eds. Yolton, Porter, Rogers \& Stafford (Oxford: Blackwell, 1991), Johan Henrik Kellgren served as librarian (1780) and private secretary (1785) to Gustav III before becoming sole editor of StockholmsPosten in 1788, about which time his poetry shifted away from satire towards 'moral earnestness' (p. 263). This publication represents not only the penultimate thoughts of a remarkable mind, but also a debt to an old teacher and young friend.-DWN]

The eighteenth century, baroque, rococo, neo-classical, got to Sweden fairly late. In effect, its artistic flowering was in the reign of Gustav III (1772-91) when culture was as it were hurriedly shipped in from all over Europe, especially France, to turn Bœotia almost overnight into the newest Athens.

Gustav doted above all on the opera (ironic in view of his assassination, the donnée of Verdi's Un Ballo in Maschera at the hand of Ankarström in the foyer of the gorgeous new Stockholm opera house, still preserved as is), but by no means neglected poetry, painting, sculpture, and the lesser decorative arts, costume, etiquette, furniture, manners. And poetry paid him back: a clutch of good eighteenth-century versemakers - Lenngren, Leopold, Oxenstjerna - one world-class genius, Carl Michael Bellman (1740-95) - and one delicious and talented practitioner, Johan Henrik Kellgren (1751-95).

Kellgren is remarkable, if for nothing else, for a poem he wrote towards the end of his shortish life, 'Den nya skapelsen' - 'The New Creation' - a startling anticipation for 1790 in Sweden, of the romantic 
sensibility which had begun to manifest itself in England and Germany by the 1790s, but which was to make its mark a good deal later in countries on the fringe, even France and Italy. But 'The New Creation' is not characteristic of Kellgren's slender verse output and, as a whole, his work is an exemplary résumé of what had gone on in the best of European eighteenth-century verse.

What is noteworthy about Kellgren, particularly in the context of the tension in the eighteenth century between poetic sincerity and the relish for form, polish, artificiality (in the Neronian sense-Qualis artifex pereo), is his effortless mastery of the latter at the service of a genuine and unshakeable poetic intention. The appearance of 'The New Creation' in 1790 would, if nothing else, have signalled this, but in fact the previous twenty years of literary activity had distinguished Kellgren from his confrères in this regard.

Not that by pre-Romantic standards Leopold, Adlerbeth, or Oxenstjerna were insincere, any more than Pope was, but then again despite the deft elegance, the kiss of death rests coldly on pieces like 'Predikaren' ('ThePreacher'), Oxenstjerna's 'Dagens Stunder' ('Hours of the Day'), or most of, say, Franzen's large and arid output (including a close paraphrase of Pope's 'Messiah'). Kellgren passionately cared about ideals, injustices, feelings, stupidity, obscurantism, love, and turned to poetry to express them as honestly and as exactly as he could. He was not only a verse satirist, but for the best part of his twenty years, beginning in 1778 , the leading light and eventually editor of Stockholms-Posten, the foremost of the swarms of journals in Gustav's culture-mad capital, an outlet into which fed the purest waters, previous and contemporary, of the century - Addison and Steele, Montesquieu, the Encyclopædists, Voltaire, Pope, Sweden's own Addison and Steele - Olaf von Dalin (also a famous satirist, journalist, and editor of the previous generation) - and numerous others. All-round man, intimately involved with Gustav's court, with the world of journalism, of literature, ever in the thick of the controversies that mattered, and at the heart of it a true poet, the best in Sweden were it not for that accident of utter genius, Carl Michael Bellman, his bête noire, rival, eventually friend, ally, and acknowledged master.

It's tempting to view Kellgren's poetic production as a kind of penitent's progress towards the proto-Romanticism of 'The New Creation,' but there is nothing else like that poem in his canon, and the view of him as good neo-classical practitioner has on the face of it much to commend it.

Kellgren openly and consistently practiced the art of imitation from other poets, notably Horace and Propertius, producing poems no less crucial to his own poetic necessities, despite their provenance, than were Pope's of his. Kellgren's bent was more lyrical than Pope's, and his early 
poetic emphases were erotic, interesting in view of that last unexpected, platonic 'New Creation' at the end of it all. For much of his early life he was a frank eighteenth-century rationalist, a Lockean hedonist, an enjoyer of - and celebrator of - the pleasures of the flesh, not just in literature by any means. Given the restraints of contemporary poetic custom, Kellgren turned often to paraphrase, imitation, adaptation, ascription while bating little of his own urgent purpose, the sensuous chronicling of the erotic life, its central pleasure, its bittersweet ephemerality, its broken hearts, its raptures, its finite epicurean inconsequentiality: the central pleasure - the Union of the Senses, 'Sinnenas förening,' as a poem of 1778 puts it. This long piece, saturated in the Horace of the Odes, though not in this instance a systematic imitation, sums up much of the early lyric Kellgren. It is one of a number of effusions to a Horatian 'Chloe,' from whose caresses instantly 'långt större ljus förstandet funnit/om tingens halt och verklighet' - 'I found far greater light of understanding/about the worth and reality of things' (11. 12-13).

Sex rather, as for Adam and Eve, becomes a moral touchstone:

$N u$ sen dess frukt ja smaka fätt, som mig så strängt förbuden varit, jag skillnan mellan ont och gott

Now since I've had a taste of that fruit, which was so firmly forbidden me,

I can distinguish good from evil. (1l. 18-20)

This provides the excuse for a detailed catalogue of Chloe's physical charms and then the moment of sensual consummation, 'känslans segerstund' - emotion's victory-hour - which 'fully compels him to the conviction,' 'att ingen sällhet äger grund/som ej av vara sinnen gives' - 'that no bliss has any basis/that is not given by our senses'. Another of the Chloe series blends the Horatian 'Gather ye rosebuds' strain with a dash of Nordic fatality:

Hur snart den gamia nornans hand

den späda levnadsblomman bryter,

och sliter av det korta band,

som vaggan hop med båren knyterl

How soon the old norn's hand

Will break the tender bloom of life,

And wear out the brief thread

Which knits cradle together to the bier! (II.13-16)

Kellgren explicitly acknowledges a number of these early pieces to derive directly from Horace. The erotic theme is explored with just as 
much emotion and sincerity in an avowed reworking of the famous 'Pyrrha' Ode (Book I.5), as we find in pieces where the Swedish author speaks in his own voice. We recall Milton's version of the ode, 'What slender youth, bedewed with liquid odours,' and some might recall hours of pleasure browsing in Sir Ronald Storrs's volume, Ad Pyrrham. a polyglot collection of translations of Horace's Ode to Pyrrha (Oxford: Oxford University Press, 1959), devoted to nothing but translations and so forth of 'Pyrrha' in a couple of dozen languages, not, as it happens, including Kellgren's.

Like any good imitator, Kellgren puffs up Horace's lines, from sixteen to forty-two, and endows his version with a strong if irregular rhymescheme. This compensates for the 4th Asclepiads of Horace's disciplined original, but does not entirely avoid the baggy feel that most imitations emit. The basic point is that the piece is an original poem by Kellgren as much as a translation from Horace, and certainly not an exercise in translation from Horace. Lost, for instance, is that immortal flow-over from the first stanza into the second, the suspended and paradoxical 'simplex munditiis.'

Quis multa gracilis te puer in rosa perfusus liquidis urget odoribus grato, Pyrrha, sub antro? cui flavam religas comam simplex munditiis?

What little boy on lots of roses adrench in perfume is coaxing you in this pleasant grotto?

For whom, Pyrrha, do you bind your yellow hair, simple in your elegance?

This becomes in Kellgren:

Såg, Pyrrha, uem den älskarn är, som uti blomstret, ung och kär, för dina fötter bunden ligger, dig var minut sin trohet svär, och kysser bojan som han bär, och dig om evig träldom tigger? $\ddot{A} n$ snabb in dina lätta spår dig till den friska grottan följer, vars tysthet dig för tadlet döljer, vars halvdag på din blygsel rår? 
Say, Pyrrha, who your lover is,

who, young and amorous

chained in flowers lies at your feet,

swears his troth to you every moment,

and kisses the chains he wears,

and begs you for eternal servitude?

Will he promptly follow your course

to your cool grotto

whose silence hides you from reproach,

whose twilight overcomes your modesty?

Ten lines for four-and-a-half, expansion where Horace is word-tight, the odd rhyme-scheme, an aabaab followed by what Kellgren uses far more often, the abba quatrain. This is the imitator's common practice, and one can cavil only with the execution, not the theory. But there are several indications that Kellgren wishes to do more than imitate for imitation's sake. He does indeed find in Horace a kindred Epicurean spirit. There are even Chloes in Horace's Odes, and the poets' attitudes to fleshly pleasures have much in common. Horace is a trifle more easy-going, and there perhaps is the giveaway. Whether in erotic lyric, satire, or philosophic discourse, there is an edge to Kellgren which bespeaks a great deal more than literary paltering, an urgent commitment to the matters under concern and an almost Romantic need to get them out in poetry. Yes, the venerable reassurance of plugging in to a tradition, the promise that other men, women, and poets have felt what you have felt, are pertinent here, but flip even through Storrs, and you find dozens of examples where Pyrrha is being played with because it is the literary thing to do. I, the least poetic soul alive, have translated 'Pyrrha' myself, twice, attracted purely by the technical challenges and the, by definition, insoluble conundrums. But poetry isn't conundrums. Kellgren's version of Pyrrha, replete as it is with many of the hallmarks of the literary imitation is, in the end, a poem by Kellgren, and part of an output in which the poet argued out and anguished over aspects of which which troubled and confused him. There is the puzzle of 'The New Creation,' a thoroughly 'Romantic' piece, and that puzzle is all the harder to solve if we cannot see the earlier poems about love as more than mere trifling.

Eroticism was by no means the only subject on which Kellgren felt a kinship with his Roman predecessor. There are other erotic odes, even involving Chloe herself, which attract Kellgren's attention, such as Book I.23, in Horace, 'Vitas inuleo me similis, Chloe' ('You avoid me, Chloe, like a fawn'), which enable him to plug into the huge European tradition of 'startled fawn/frightened little girl on the threshold of her first erotic experience' minstrelsy. Kellgren deftly turns Horace's twelve lines here into a terse nineteen, again irregularly rhymed, but pretty close to Horace 
and pretty close to Kellgren's current poetic preoccupations. He preserves the lonely mountains, the little breeze which is in sort the fawn herself, the quivering leaves, the terror of the interlocutor who might well be a natural enemy like a lion, although Horace's tiger becomes a bear and, alas, we lose the lizards, the dazzling 'virides lacertæ'. But the subject fits Kellgren: literary ingenuity is a secondary consideration.

There are, though, in Horace non-erotic themes that speak to the moralist and satirist in Kellgren, though here we are speaking distinctly of subject-matter and not manner. One such is Book II, Ode 10, 'Rectius vives, Licini,' one of Horace's most famous aurea mediocritas poems. 'Min vän, att rätta kosan lära' expands Horace's twenty-four lines to twentyeight, rhymes in quatrains again, though mixing abbas with ababs, and generally hewing quite close to Horace's imagery and line of argument. Again, there is a vitality and edge to the Swedish which argues strong agreement with the chosen original. Wide reading does this to us, indeed - it's why we keep commonplace books and even commit to memory our favourite pieces. But we don't always write poems, and passionately felt poems on everything that has specially touched us.

Kellgren was steeped in European and classical literature, he knew his French contemporaries thoroughly and had a classical grounding a great deal solider than, say, Pope's. But direct traces of these are almost totally absent, or so generalized as to be unprovable. One might detect a whiff of Anacreon or Alcæus, a glance at Catullus, a pass at the Pléiade, a pinch from the previous Swedish generation of Creutz or Gyllenborg. But there is no direct evidence, no way of knowing. The only other poet we can be sure of that Kellgren overtly imitated is another Augustan Roman, Sextus Propertius who so malignly drew the attention of the ridiculous Ezra Pound in our own century. There is one extraordinary piece, possibly the only one in Kellgren which might nudge us somewhere towards the territory of 'The New Creation.' This is 'Över Propertii Byst' - 'On a Bust of Propertius' — not taken directly from anything of the Roman poet's, but imbued with his spirit, and a powerful and moving utterance on Kellgren's own behalf.

Blekt mitt anlete är, men tadlen konstnären icke, att han det gjort så blekt. Sådan I livet jag var.

Riktigt bildades så den färg som Cynthia gav mig, blodet torkade bort, kinderne vissnade hän.

Ungdom och hälsa och lycka och lugn, allt offrades henne,

hennes jag levande var, hennes I döden jag är.

Livet flyktade snart - men ack, när ägde jag livet?

Nej, genom Cynthia blott var ju Propertius till. 
Pale is my face, but blame not the artist,

That he made it so pale. Thus in life I was

The colour Cynthia gave me is correctly rendered,

Blood drained away, cheeks faded.

Youth and health and happiness and peace, all given her,

Hers was I living, hers in death I am,

Life soon fled - but, ah, when had I life?

No, through Cynthia only did Propertius exist.

The erotic pessimism of this is miles away from the lascivious dallying of the Chloe poems and their like, but eerily Propertian in tone and cognate with a sheaf of other Kellgren poems which explore a fearful state of pessimistic desolation about the meaning of life in general, not just the sulks of erotic deferment. There is also a full-scale paraphrase or imitation of a Propertius 'carmen,' Book II.15 'O me felicem! o nox mihi candida! et o tu,' the one with the great Catullean line 'nox tibi longa venit, nec reditura dies' ('the long night comes for you, and day will not return').

Propertius begins with a rapturous evocation of the past night of love: 'How happy I am! O perfect night! O bed made blessed by my ecstasies!' He chides Cynthia for her reluctance to make love completely naked, appealing to precedents such as Paris and Helen and Diana and Endymion. Delay no sensual refinement, the long night will come and day will not return. True love knows no limits, and rivers will have to run backwards up mountains before Propertius could imagine switching his allegiance. 'Alive I am hers, and I will be hers when I'm dead,' a line which appears verbatim in the Bust poem above:

Hers was I living, hers in death I am.

But if she will grant me more nights

with her like that, a year will be a long life for me.

If everyone gave way to sensual pleasure

there would be no more war.

If tomorrow is the end, it's been a life well-spent.

Kellgren follows Propertius very closely here. He begins with a steamy celebration of the night's raptures, expands the Roman's complaint about the refusal of nakedness, and modulates into the sombre meditation on transience and death which has begun to pervade his non-erotic poetry. Fröja replaces Venus, but the ethos is identical. In the face of swift impending death the only resort is to more love-making which might preclude war and even, as with Propertius, exalt the lover to temporary godhead, a notion which appears more than once in Kellgren, notably in 'The Union of the Senses.' Propertius ends by noting that what he has chosen to do has not added to the sum of the world's woes, and Kellgren 
follows his lead. The last image in the Latin is of vine-leaves from withered garlands floating and drifting in the wine-bowls, paraphrased here by the Swede into a single leaf from a proud tree borne away by a stream or river as he and the Swedish Cynthia will soon be borne away by time. The Propertian temperament is rather close to Kellgren's, too close, perhaps, for extended imitation.

What, though, is Kellgren's temperament? While a great deal of his important poetic work lay in the erotic lyric and the expression of black despair, his life's work and the rest of his poetry was robustly satiric. As we have seen, he earned his living as a journalist, but a journalist whose strong affinity was for satire, verse and prose, a man who fought a number of the good fights. One of these was the passionate debate between those who believed poetry should be 'original' and those who expected it to stick to the rules. Highly influential in Sweden during Kellgren's lifetime was Young's Conjectures on Original Composition (1759), whose argument Kellgren at first opposed, one of the fundamental causes of his initial hostility to Bellman, an utterly free spirit if ever there was one. In a wonderful piece from 1778, 'Mina Löjen' ('Things I Laugh At'), Kellgren excoriates Bellman and those like him who wrote the way they chose regardless of precedent and rule. Only perhaps as the mood of 'The New Creation' came over him did Kellgren come round full circle, until he felt able to write the magnanimous preface he supplied to his rival's supreme masterpiece, Fredmans Epistlar (1790). Genius, Kellgren now claims, has the right, even the duty to proceed as it chooses. Some have detected in the Preface a lingering reluctance to say goodbye to all the principles of the Enlightenment, and it would be odd if Kellgren did not have a regret or two. But something had happened to him inside, as the writing of 'The New Creation' was soon to show.

In any case the satire could remain relatively unchanged, and it is perhaps here that Kellgren could most comfortably maintain his links with eighteenth-century principles and practice. Kellgren's ferocity was far from abated as his awareness of the operations of fools and villains and madmen sharpened. Among poems contemporary with, or later than, 'The New Creation' are pieces with such titles as 'The Lives of Fools' and 'The Enemies of Light.' The tone here is rather far from Horatian. Really, it's pure Juvenal, pure Swift, a rage and fury which bursts the bounds of rules and taste and easygoing tolerance. The arena is often literary, but with increasing confidence Kellgren steps out on to the great stage of the world. Bitterly he reminds the fools in 'Man äger ej snille för det man är galen' ('Man, you're not a genius just because you're mad'): 
Pope puckelryggig var, Homer och Milton blinda.

Att deras likar bli, gott folk, vad tarvas mer,

än sètta puckeln på, och ögonen förbinda.

Pope was hunchbacked, Homer and Milton blind.

Be in their likeness, good folk, what more is needed

Than to tie a hump on, blindfold the eyes.

Kellgren is on the cusp - poetically, politically, socially - of great upheavals. This is foreshadowed in 'The New Creation,' the Bellman preface and much else. But that is not the motor of his passion, satiric or erotic. Kellgren has inhabited a period during which an empire and a culture has slowly decayed, artificially lit up by the glitter of Gustav's reign. His disgust, his erotic selfishness, his black despair are all particularly hardly won. But the sense of sharing them with men and woman of honesty and goodwill at any given time in human history is equally potent. When we are addressing this perennially fascinating topic of the relationship between precedent and originality in literature, it makes Johan Henrik Kellgren, I think, an especially cogent exemplar.

\section{MICHAEL B. THOMPSON}

Carleton University 